\title{
OS FRANCISCANOS NA PARAÍBA: FORMAÇÃO RELIGIOSA, INSTRUÇÃO E LIVRARIA CONVENTUAL (SÉCULOS XVIII E XIX) ${ }^{1}$
}

DOI: http://dx.doi.org/10.1590/2236-3459/64462

\author{
Carla Mary S. Oliveira \\ Universidade Federal da Paraíba (UFPB), Brasil
}

$\cos 8$

\begin{abstract}
Resumo
O artigo analisa a atuação dos frades franciscanos da Província de Santo Antônio do Brasil, no campo da Instrução intra e extramuros, com foco especial sobre a Paraíba entre os séculos XVIII e XIX. Pretende-se, por meio da documentação consultada, compreender como eram designadas as funções de mestre e lente entre os franciscanos, bem como identificar, a partir de duas Relações elaboradas pelo superior provincial em 1779 e remetidas à rainha D. Maria I, quais dentre os frades professos da província as exerciam. Analisa-se também a importância das livrarias conventuais para as atividades de docência dos franciscanos, bem como o acervo da livraria da casa paraibana, por meio de inventário elaborado pela Ordem em 1852.

Palavras-chave: franciscanos, instrução, livrarias conventuais, séculos XVIII e XIX, Paraíba.
\end{abstract}

\section{THE FRANCISCANS IN PARAÍBA: \\ RELIGIOUS FORMATION, EDUCATION AND CONVENTUAL LIBRARY (18 ${ }^{\mathrm{TH}}$ AND $19^{\mathrm{TH}}$ CENTURIES)}

\begin{abstract}
This paper analyses the intra and extramural educational work of Franciscan Friars in the Province of St. Anthony of Brazil, with special focus on Paraíba, between $18^{\text {th }}$ and $19^{\text {th }}$ centuries. The paper intends, basing upon some documental sources, understand how the Friars were designated to teach and lecture functions and identify, from two lists established by the provincial superior in 1779 and sent to Queen Mary I from Portugal, which of the professed friars of the Province exercised these functions. The importance of monastic libraries for teaching activities of Franciscans in the entire religious Province is also analysed, as well as the library's collection of Paraiba convent through an inventory done by the Order in 1852.

Keywords: franciscans, education, monastic libraries, $18^{\text {th }}$ and $19^{\text {th }}$ centuries, Paraíba.
\end{abstract}

\footnotetext{
1 Este artigo traz parte dos resultados do projeto de pesquisa Os franciscanos e a Pedagogia Seráfica: primeiras letras, catequese e moral cristã no Brasil (séculos XVIII e XIX), desenvolvido entre abril de 2014 e agosto de 2016 com a colaboração dos bolsistas Damião Oliveira Neto e Lucas Gomes Nóbrega, graduandos do Curso de Licenciatura em História da Universidade Federal da Paraíba (Pibic/UFPB/CNPq).
} 


\section{LOS FRANCISCANOS EN PARAÍBA: \\ FORMACIÓN RELIGIOSA, EDUCACIÓN Y BIBLIOTECA CONVENTUAL (SIGLOS XVIII Y XIX)}

\section{Resumen}

El artículo analiza la actuación de los Frailes Franciscanos de la Provincia de San Antonio de Brasil en el campo de la instrucción intra y extra muros, con especial énfasis en la Paraíba de los siglos XVIII y XIX. Se pretende, a través de la documentación consultada, comprender cómo se designaron las funciones de maestro y lector entre los franciscanos, identificándose, a partir de dos relaciones preparadas por el superior provincial en 1779 y enviados a la reina María I de Portugal, quién de los profesos de la provincia las ha ejercido. También se discurre acerca de la importancia de las bibliotecas monásticas para las actividades docentes de los franciscanos y sobre la colección de la biblioteca del convento de Paraíba, por medio de un inventario elaborado por la Orden en 1852.

Palabras clave: franciscanos, educación, bibliotecas conventuales, siglos XVIII y XIX, Paraíba.

\section{LES FRANCISCAINS EN PARAÍBA: FORMATION RELIGIEUSE, ÉDUCATION ET BIBLIOTHĖQUE CONVENTUELLE (XVIIIE ET XIXE SIÉCLES)}

\section{Résumé}

L'article analyse la activité des frères franciscains de la Province de Saint-Antoine du Brésil dans le domaine de l'enseignement intra et extra-murs, avec un accent particulier sur la Paraíba entre les XVIIle et XIXe siècles. II est voulant, à travers la documentation consultée, comprendre comment les fonctions de maître et lecteur entre les Franciscains ont été désignés et identifier, à partir de deux relations établies par le supérieur provincial en 1779 et envoyés à la reine Marie I de Portugal, qui, parmi des profès de la province, exercés cettes functions. S'examine également l'importance des bibliothèques monastiques pour les activités d'enseignement des Franciscains et la collection de la bibliothèque de le convent de Paraíba en utilisant l'inventaire établi par l'Ordre en 1852.

Mots-clés: franciscains, éducation, bibliothèques conventuelles; XVIIle et XIXe siécles, Paraíba. 
$\mathrm{P}$

ara Tania Iglesias (2012, p. 115-117) um dos grandes problemas no que se refere aos estudos sobre a atuação franciscana no campo da Educação durante o período colonial na América Portuguesa reside na característica de as fontes da Ordem dos Frades Menores serem escassas e, mais ainda, pelo fato de ser arraigada a ideia, entre os historiadores, de que os seráficos ${ }^{2}$ teriam se dedicado muito mais à catequese como parte de sua missionação do que ao ensino das primeiras letras e da gramática latina aos gentios convertidos ou aos filhos dos colonos. Tradicionalmente, estabeleceu-se a concepção de que este tipo de ensino no Brasil colonial estava ligado a outras ordens religiosas, dentre as quais se destacariam, sem dúvida, os inacianos, os beneditinos, os dominicanos, os oratorianos e os carmelitas.

Além disso, há que se considerar também que mesmo as crônicas da própria ordem que tiveram como tema a Província Franciscana de Santo Antônio do Brasil ${ }^{3}$ são relativamente escassas nos séculos XVII e XVIII - se comparadas à documentação produzida pelos jesuítas, por exemplo - e tratam o tema de forma muito breve, como o manuscrito seiscentista Narrativa da Custódia de Santo Antônio do Brasil, do Fr. Manuel da Ilha, que aborda o período de 1584 a 1621 e foi publicado apenas em 1975, e o Novo Orbe Seráfico Brasílico, de Fr. Antonio de Santa Maria Jaboatão, que teve sua primeira parte publicada em 1761 e a restante somente em 1858, quando de sua segunda edição, financiada pelo Instituto Histórico e Geográfico Brasileiro - IHGB. Também se constituem em fontes documentais indispensáveis para o tema os Estatutos da Província de S. Antonio do Brasil, publicados em Lisboa em 1709, e as Atas Capitulares da Província de Santo Antônio do Brasil (1649-1893), transcritas, comentadas e publicadas pelo Fr. Venâncio Willeke na Revista do IHGB em 1970. A este corpus se juntam alguns esparsos documentos avulsos do Arquivo Histórico Ultramarino - $\mathrm{AHU}^{4} \mathrm{e}$, certamente, $\mathrm{o}$ acervo ainda pouquíssimo explorado do Arquivo Provincial Franciscano do Recife.

O que sempre se frisou quanto aos franciscanos e sua atuação na América portuguesa é que a grande preocupação desses religiosos no que se refere à instrução concentrava-se essencialmente na formação de seus próprios noviços, no que tange ao domínio do latim e de sua gramática, das Sagradas Escrituras e da doutrina católica e de sua interpretação e disseminação entre os seculares. Extramuros, se considerava que o interesse da Ordem era quase que de todo dedicado à catequese, com esporádicos casos de instalação de aulas de primeiras letras a pedido dos colonos, como sugerem algumas solicitações feitas pelo povo da Paraíba ao Conselho Ultramarino durante o período colonial $^{5}$. Mas essa é uma visão equivocada, como salienta Tania Iglesias, e merece, por

2 Os franciscanos também são conhecidos por "seráficos", numa alusão à visão revelada a São Francisco durante sua suposta estigmatização, momento em que, em êxtase, o santo teria visto o próprio Cristo coberto por três pares de asas de serafim pairando sobre ele no céu e derramando os raios que criaram suas próprias chagas no corpo do poverello, cerca de dois anos antes de sua morte.

${ }^{3}$ A Província de Santo Antônio do Brasil, que em 1657 sucedeu à Custódia homônima ereta em 1584 e ainda vinculada à Província portuguesa de mesmo nome, englobava, tanto no período colonial como no imperial, os conventos de Conde, de Cachoeira, de Cairu e de Salvador, na Bahia; de São Cristóvão, em Sergipe; de Penedo, da Vila de Alagoas, de Sirinhaém, de Ipojuca, de Igarassu, de Recife e de Olinda em Pernambuco; e da Cidade da Paraíba, cabeça da capitania/ província de mesmo nome, totalizando treze casas franciscanas.

${ }^{4}$ Disponíveis para consulta e download no sítio eletrônico da Biblioteca Nacional do Rio de Janeiro, como resultado das ações do Projeto Resgate Barão do Rio Branco, patrocinado pelo Ministério da Cultura - MinC.

${ }^{5}$ OFÍCIO do [governador da Paraíba], brigadeiro Jerónimo José de Melo e Castro, ao [secretário de estado da Marinha e Ultramar], Martinho de Melo e Castro, sobre a capitania ter ficado sem mestres de gramática, 
isto mesmo, ser revista por meio de pesquisas dedicadas à História da Educação.

\section{Os frades franciscanos e suas funções na vida religiosa}

Um bom exemplo para se mostrar o quão equivocada é a interpretação acerca da atuação dos seráficos no campo da instrução ao longo do período colonial pode ser encontrado em um documento enviado a D. Maria I, em novembro de 1779, pelo provincial franciscano, Fr. Domingos da Purificação ${ }^{6}$. Em resposta a uma solicitação da Coroa, 0 religioso fez um longo arrazoado, solicitando a autorização para receber noviços, dada a penúria de alguns conventos quanto ao exercício de suas plenas atividades, tendo em vista a escassez de frades na Província. A carta à rainha vai acrescida de vários anexos, onde se dá conta do número de frades professos e noviços, discriminando inclusive suas atribuições na congregação. Trata-se de conjunto de registros extremamente relevante para se esclarecer alguns detalhes quanto ao número de frades da Província em diferentes momentos do século XVIII7, tema de singular importância tendo em vista as proibições régias que surgiram anos antes, a partir do governo de D. José I, quanto à admissão de postulantes nas ordens religiosas instaladas nas terras sob o jugo da Coroa portuguesa ${ }^{8}$. Num desses anexos, uma certidão transcrevendo, em cópia, a representação feita junto à Coroa em julho de 1739 pelo provincial de então, Fr. Manoel da Ressurreição, também se solicitava a permissão para aceitar noviços:

Cada hum dos conventos necessita de ter Guardião, Prezidente, Porteiro, Sachriztão, Despenceiro, Comissario dos Irmaõs Treceiros, Mestre que ensina gramatica aos filhos dos moradores, ao menos quatro coristas, que com hum ou dous velhos são doze ou treze frades [...]; seis confessorez não bastão porque os nossos conventos estão dentro das villas; quatro Pregadores e quatro ou seis esmoleres para os peditórios: isto he nos conventos mais pequenos e das vas [...]. Pello que observey pelas vizitas dos conventos, e o que a experiência tem estimado, pareceme que os dez conventos menores necessitam de vinte e cinco frades ao menoz $[\ldots] .^{9}$

Qual seria o sentido de que, ao solicitar o aumento do número máximo de frades professos na Província, seu superior usasse como justificativa a função de mestre de gramática exercida extramuros pelos religiosos, senão o fato de ser esta uma prática usual

com a expulsão dos jesuítas; e propondo que os padres franciscanos exerçam a função. Cidade da Paraíba, 06 nov. 1766 (AHU_ACL_CU_014, Cx. 25, D. 1977). CARTA dos oficiais da Câmara da Paraíba, ao rei [D. José I], sobre a necessidade de professores para substituírem os jesuítas; e propondo o aproveitamento dos clérigos das ordens de São Bento, São Francisco e do Carmo, existentes naquela cidade. Cidade da Paraíba, 30 abr. 1772 (AHU_ACL_CU_014, Cx. 25, D. 1925). O governo da capitania paraibana enviou sucessivos pedidos por mestres de gramática, entre 1765 e 1782 (Ver: AHU_ACL_CU_014, Cx. 23, D. 1759; Cx. 23, D. 1783; Cx. 24, D. 1862; Cx. 24, D. 1883; Cx. 25, D. 1943).

${ }^{6}$ CARTA do provincial da Província de Santo Antonio do Brasil, Frei Domingos da Purificação, à rainha [D. Maria I], sobre a Relação dos Religiosos da Ordem Franciscana em cada um de seus conventos. Recife, 11 nov. 1779. Anexos: 6 docs. AHU_ACL_CU_015, Cx. 135, D. 10107.

${ }^{7}$ A representação de 1739, cuja cópia consta em anexo à carta de Fr. Domingos da Purificação, registra 419 frades na Província para aquele ano (AHU_ACL_CU_015, Cx. 135, D. 10107, Anexo 5), e Fr. Venâncio Willeke, remetendo a documentos do Arquivo Provincial, registra em nota que em 1763 havia 470 professos espalhados nos 13 conventos e nas missões seráficas entre a Bahia e a Paraíba, divididos "entre sacerdotes, estudantes e irmãos" (ATAS, 1970, p. 222).

8 Essas proibições, na verdade, selariam o destino da Província de Santo Antônio do Brasil, que entrou no Oitocentos já bem depauperada de religiosos em seus quadros e só viu a situação se agravar cada vez mais durante aquela centúria.

${ }^{9}$ AHU_ACL_CU_015, Cx.135, D. 10107. Anexo 5. Grifos meus. 
para os franciscanos, em 1739 instalados já há cerca de século e meio naquelas paragens das Capitanias do Norte do Estado do Brasil?

Os Estatutos de 1709 reafirmavam aquilo que havia sido estabelecido quando da criação da Província franciscana em 1657: o total de frades professos e residentes em seus conventos ficaria limitado a 236 religiosos, sendo 24 o teto para o convento da Paraíba (ESTATUTOS, 1709, p. 228). Esse total geral foi elevado para 400 em 1740, por meio de um Aviso Real emitido pelo Conselho Ultramarino, em resposta, justamente, à representação encaminhada a Lisboa pelo provincial franciscano em 1739, da qual se transcreveu o trecho acima. $\mathrm{O}$ argumento apresentado pelo provincial à Coroa portuguesa era o de que o aumento do número de religiosos seria necessário para que os conventos pudessem funcionar a contento, com os frades cumprindo todas suas atividades internas e externas, e entre essas se colocava claramente aquela em que os franciscanos, ao menos um em cada cenóbio, deveriam atuar como mestres de gramática extramuros.

Ora, o documento de 1739 enumera tal atividade de docência antes daquelas de coristas $^{10}$, confessores ${ }^{11}$, pregadores ${ }^{12}$ e esmoleres ${ }^{13}$, colocando-a depois apenas dos cargos essenciais para o funcionamento da casa conventual, ou seja, as aulas extramuros aparecem como ações fulcrais para a vida missionária dos franciscanos, constituíam-se numa das várias maneiras de os religiosos de Assis agirem no século, de exercerem sua vocação. Daí e, certamente, também dos estudos religiosos desenvolvidos no ambiente intramuros é que parece ter se construído a ideia de erudição associada aos frades, o que explicaria a reflexão feita por Fr. Domingos da Purificação ao final de sua longa argumentação na carta de 1779 à rainha:

Nem menos he digna destas lagrimas a falta $q$ vai padecendo esta Provincia, de Letras e decadencia noz exercicios literários, p não haver Religiozos mancebos, em $\underline{\text { cujo aproveitame to }}$ exercitandose o magisterio não falte a mesma $\underline{\text { Prova }}$ o esplendor da literatura assim nas aulas como nos pulpitos, e conseguintem ${ }^{\text {te }}$ cresçaõ os obreiros na vinha da Igreja $p^{a}$ a colheita da Seara Evangelica. ${ }^{14}$

10 O corista é o "Religioso moço, que serve no coro" (BLUTEAU, 1712, v. 2, p. 549). O Coro, por sua vez, trata-se, ainda segundo Bluteau, do "lugar da Igreja, em que se cantaõ os Officios Divinos". (BLUTEAU, 1712, v. 2, p. 553).

${ }_{11}$ Para Bluteau, trata-se do "Sacerdote, que tem faculdade para ouvir confissão" (BLUTEAU, 1712, v. 2, p. 454). Os franciscanos da Província de Santo Antônio do Brasil faziam distinções entre as atribuições dos confessores "de frades" e "de seculares": os que agiam intramuros deveriam ter no mínimo trinta anos de idade e ao menos quinze de hábito, além de terem de se submeter a um exame conduzido "por dois Religiosos doutos", em que os frades que pretendessem a função seriam inquiridos sobre "censuras Eclesiasticas, Sacramentos da Igreja, \& preceytos Divinos" antes de receberem a chancela para de fato exercer a função nos conventos. Já no caso dos confessores que agiriam extramuros, atendendo aos moradores "seculares", esses além de se submeter à mesma inquirição daqueles que agiriam intramuros, também deveriam ter "estudo, modéstia, \& approvada vida, \& que passem de trinta annos de idade para ouvirem confissões de homens, \& de quarenta para mulheres, \& que tenham vinte annos de habito". (ESTATUTOS, 1709, p. 39).

12 Segundo o Vocabulario Portuguez \& Latino de Raphael Bluteau, trata-se do religioso "que préga a palavra de Deos" (BLUTEAU, v. 6, 1720, p. 691). No caso dos franciscanos, estes frades tinham por obrigação proferir sermões nas igrejas conventuais e também em praça pública, e para fazê-lo deveriam ter um grande conhecimento das escrituras. Nos Estatutos de 1709 há todo um capítulo sobre esta função. Ver: ESTATUTOS, 1709, p. 41-42.

${ }^{13}$ Numa ordem mendicante, o esmoler é o frade que recebe a responsabilidade de distribuir as esmolas aos pobres (BLUTEAU, 1712, v. 3, p. 251). Entre os franciscanos, era também aquele designado para fazer os peditórios, ou seja, recolher doações de filantropos e redistribuí-las aos necessitados.

${ }_{14}$ AHU_ACL_CU_015, Cx. 135, D. 10107. Grifos meus. 
Assim como em 1739, os próprios franciscanos destacavam, quarenta anos depois e também em documento oficial encaminhado a Lisboa, que fazia parte de suas atividades a condução de aulas e, nesse caso, se pode inferir que a função de mestre era atribuída aos "religiosos mancebos", ou seja, àqueles com energia e saúde para lecionar principalmente fora dos conventos. Anexos a esta carta a D. Maria I constam duas listagens nominais dos frades professos, separados entre nacionais e europeus, e uma terceira com os noviços em formação, dando, no caso desses últimos, sua filiação - garantia de limpeza de sangue - e origem por bispado. Os dados permitem não somente se ter uma noção bem fundamentada do tamanho da Província mas também, e principalmente, da distribuição destes frades pelas diversas funções existentes dentro das casas religiosas seráficas, como se pode ver na Tabela 01:

Tabela 01 - Funções exercidas pelos frades professos da província franciscana de Santo Antônio do Brasil $-1779^{15}$

\begin{tabular}{l|c|c|c|c|c|c}
\hline \multicolumn{1}{c|}{ FUNÇÃO } & NACIONAIS & $\%$ & EUROPEUS & $\%$ & TOTAL & $\%$ \\
\hline Pregador & 102 & 33,44 & 48 & 15,73 & 150 & 49,18 \\
\hline Confessor $^{16}$ & 48 & 15,73 & 25 & 8,19 & 73 & 23,93 \\
\hline Lente $^{17}$ & 22 & 7,21 & 6 & 1,96 & 28 & 9,18 \\
\hline Leigo $^{18}$ & 6 & 1,96 & 21 & 6,88 & 27 & 8,85 \\
\hline Ex-Definidor & 5 & 1,63 & 9 & 2,95 & 14 & 4,59 \\
\hline Ex-Custódio19 & 1 & 0,32 & 2 & 0,65 & 3 & 0,98 \\
\hline Sacristão & 1 & 0,32 & - & - & 1 & 0,32 \\
\hline Ex-Provincial & 1 & 0,32 & 3 & 0,98 & 4 & 1,31
\end{tabular}

${ }^{15}$ AHU_ACL_CU_015, Cx. 135, D. 10107. Anexos 1 e 2.

16 Para Bluteau, trata-se do "Sacerdote, que tem faculdade para ouvir confissão" (BLUTEAU, 1712, v. 2, p. 454). Os franciscanos da Província de Santo Antônio do Brasil faziam distinções entre as atribuições dos confessores "de frades" e "de seculares": os que agiam intramuros deveriam ter no mínimo trinta anos de idade e ao menos quinze de hábito, além de terem de se submeter a um exame conduzido "por dois Religiosos doutos", em que os frades que pretendessem a função seriam inquiridos sobre "censuras Eclesiasticas, Sacramentos da Igreja, \& preceytos Divinos" antes de receberem a chancela para de fato exercer a função nos conventos. Já no caso dos confessores que agiriam extramuros, atendendo aos moradores "seculares", esses além de se submeter à mesma inquirição daqueles que agiriam intramuros, também deveriam ter "estudo, modéstia, \& approvada vida, \& que passem de trinta annos de idade para ouvirem confissões de homens, \& de quarenta para mulheres, \& que tenham vinte annos de habito". (ESTATUTOS, 1709, p. 39).

17 Bluteau define o termo como "Mestre que dá postilla. Doutor que lé aos seus discipulos algữa sciencia" (BLUTEAU, 1716, v. 5, p. 80). Nos Estatutos provinciais de 1709 há trechos específicos sobre os lentes de Filosofia (Capítulo XV) e de Teologia (Capítulo XVI). (ESTATUTOS, 1709, p. 33-34).

18 Trata-se de religioso "Pouco instruido naõ só em materias Ecclesiasticas, mas tambem em letras, \& sciencias humanas. [...] Frade leigo, Irmaõ leigo. Irmaõ de alguma Ordem. Nas Religioens he aquelle, que não sendo nem Corista, nem Sacerdote, serve nos mais humildes officios do Convento" (BLUTEAU, 1716, v. 5, p. 70). O Capítulo $X$ dos Estatutos estabelece as funções dos religiosos leigos dentro dos conventos da Província, entre as quais os serviços da cozinha, a realização de pequenas tarefas a mando do superior fora da casa conventual e pelo bem da comunidade, o trabalho nas oficinas e a assistência aos irmãos idosos. (ESTATUTOS, 1709, p. 27-29).

${ }^{19}$ Custódio é superior regional de um conjunto de conventos que ainda não formam uma província e sim uma custódia; dentro de uma província o custódio exerce o cargo de vice-provincial. (WILLEKE, 1956, p. 258). 


\begin{tabular}{l|c|c|c|c|c|c}
\hline \multicolumn{1}{c|}{ FUNÇÃO } & NACIONAIS & $\%$ & EUROPEUS & $\%$ & TOTAL & $\%$ \\
\hline Definidor $^{20}$ & - & - & 2 & 0,65 & 2 & 0,65 \\
\hline Procurador $^{21}$ & - & - & 2 & 0,65 & 2 & 0,65 \\
\hline Provincial $^{22}$ & - & - & 1 & 0,32 & 1 & 0,32 \\
\hline Passante $^{23}$ & - & - & 1 & 0,32 & 1 & 0,32 \\
\hline TOTAL & $\mathbf{1 8 6}$ & $\mathbf{6 0 , 9 8}$ & $\mathbf{1 1 9}$ & $\mathbf{3 9 , 0 2}$ & $\mathbf{3 0 5}$ & $\mathbf{1 0 0}$ \\
\hline
\end{tabular}

Fonte: dados da documentação consultada, organizados pela autora.

A relação de 1779 discrimina apenas os lentes e o passante, ou seja, os mestres e o aspirante responsáveis pelas aulas de Filosofia e Teologia, desenvolvidas nas casas de Olinda e Salvador, no caso dos estudos superiores (ESTATUTOS, 1709, p. 32), e Paraguaçu e Igarassu, no caso dos estudos introdutórios (ATAS, 1970, p. 215). Por meio da relação desses mestres se pode chegar ao menos a uma constatação, a de que a chancela de lente, para lecionar Filosofia e Teologia aos noviços nos estudos de formação religiosa e filosófica, era algo que só se outorgava aos frades com certa experiência, como se pode ver pelo Quadro 01: o único passante listado em 1779, Fr. Vitorino do Espírito Santo, natural da Europa, já tinha 18 anos de hábito e ainda aguardava seus exames para assumir a função de lente. Todos os outros lentes da Província à época tinham mais de 20 anos de vida religiosa, sendo que metade deles já ultrapassava os 30 anos de hábito.

Quadro 01 - Frades dedicados à docência de filosofia e teologia (lentes) na província franciscana de Santo Antônio do Brasil - 177924

\begin{tabular}{|l|c|c|c|}
\hline \multicolumn{1}{|c|}{ FRADE } & TEMPO DE HÁBITO & ORIGEM & OUTRA FUNÇÃO \\
\hline José de Santa Clara Mello & 64 anos & nacional & - \\
\hline Laureano de São José & 56 anos & europeu & - \\
\hline Antônio de Santa Maria Traripe & 55 anos & nacional & - \\
\hline Serafim de Santo Antonio & 53 anos & nacional & - \\
\hline Anselmo da Apresentação & 50 anos & nacional & - \\
\hline João de Deus & 49 anos & nacional & Ex-Definidor \\
\hline Leandro do Sacramento & 48 anos & europeu & Ex-Custódio \\
\hline João dos Milagres & 46 anos & nacional & Ex-Custódio \\
\hline José da Conceição Gama & 43 anos & nacional & - \\
\hline
\end{tabular}

20 Segundo Bluteau, trata-se de "Termo de certos Religiosos. He o conselheyro do Geral ou do Provincial". (BLUTEAU, 1712, v. 3, p. 37).

${ }^{21}$ Representante legal da Província franciscana em Portugal. A Província de Santo Antônio do Brasil mantinha um procurador geral em Lisboa e outro, auxiliar, na cidade do Porto em 1779.

${ }_{22}^{2}$ Superior de um conjunto de conventos que formam uma província independente. (WILLEKE, 1956, p. 258).

${ }^{23}$ Bluteau esclarece que "Em Collegios Religiosos he o Estudante, que tendo acabado seus annos de estudo, espera certo tempo para entrar nas cadeyras, \& passar a ser mestre". (BLUTEAU, 1720, v. 6, p. 299).

${ }^{24}$ AHU_ACL_CU_015, Cx. 135, D. 10107. Anexos 1 e 2. 


\begin{tabular}{|c|c|c|c|}
\hline FRADE & TEMPO DE HÁBITO & ORIGEM & OUTRA FUNÇÃO \\
\hline João do Rosário & 39 anos & nacional & - \\
\hline Luís de Santo Antônio & 39 anos & nacional & Ex-Definidor \\
\hline Antônio dos Santos Passos & 38 anos & nacional & - \\
\hline Félix do Rosário & 35 anos & nacional & - \\
\hline Manoel do Monte do Carmo & 35 anos & nacional & - \\
\hline Manoel da Sant'Ana & 33 anos & nacional & - \\
\hline $\begin{array}{l}\text { Francisco Xavier de Santa } \\
\text { Thereza }\end{array}$ & 32 anos & nacional & - \\
\hline José de São Bernardo & 31 anos & nacional & - \\
\hline Manoel da Conceição & 31 anos & nacional & - \\
\hline José Maria do Santíssimo & 29 anos & nacional & - \\
\hline Manoel de Santa Rosa & 29 anos & nacional & - \\
\hline Raimundo de Santa Tereza & 29 anos & nacional & - \\
\hline Antônio de Santa Eugênia & 28 anos & europeu & - \\
\hline Antônio da Encarnação & 28 anos & europeu & - \\
\hline Antônio da Expectação & 28 anos & europeu & - \\
\hline Francisco dos Arcanjos & 28 anos & europeu & - \\
\hline Boaventura de São José & 26 anos & nacional & - \\
\hline Paulino de Sant'Ana & 23 anos & nacional & - \\
\hline Alexandre de Santo Inácio & 20 anos & nacional & - \\
\hline $\begin{array}{l}\text { Vitorino do Espírito Santo } \\
\text { (passante) }\end{array}$ & 18 anos & europeu & - \\
\hline
\end{tabular}

Fonte: dados da documentação consultada, organizados pela autora.

Quanto aos frades mestres de gramática, é preciso usar outro artifício para identificálos, ao menos no que se refere àqueles presentes nessas duas relações de 1779: há, no Arquivo Provincial do Recife, o Liber Mortuorum ${ }^{25}$, onde estão listados os irmãos seráficos falecidos na Província de Santo Antônio do Brasil entre 1585 e 1810. Nele estão registradas as funções exercidas pelos frades defuntos, incluindo a de mestre de gramática, o que permite que se tenha uma ideia aproximada de quais religiosos, dentre os listados em 1779 e falecidos até 1810, estiveram, em algum momento, à frente dessas aulas, fossem elas realizadas intra ou extramuros. Cruzando as duas fontes, é possível chegar aos dados apresentados no Quadro 02:

${ }^{25}$ Arquivo Provincial Franciscano do Recife - APFR, Pacote 20, Livro III, 1. Liber mortuorum P. Sebastiani in quo ex variis libris antiquis collegi tnomina et indicationes mortuorum, quotquot ab initio invenire potuit ab anno 1585 usque ad 1810. 
Quadro 02 - Frades defuntos que exerceram a docência de gramática na província franciscana de Santo Antônio do Brasil - 1779/181026

\begin{tabular}{|c|c|c|c|c|}
\hline FRADE & ORIGEM & $\begin{array}{l}\text { INGRESSO } \\
\text { NA ORDEM }\end{array}$ & MORTE & OUTRAS FUNÇÕES \\
\hline Arnaldo de Santa Quitéria & Europa & 1727 & 1779 & $\begin{array}{l}\text { Ex-Definidor, Ex-Guardião } 27 \\
\text { Pregador, Ex-Comissário da } \\
\text { Ordem } 3^{\text {a }}\end{array}$ \\
\hline Ricardo de São Bernardino & Europa & 1727 & 1780 & $\begin{array}{l}\text { Ex-Guardião, Pregador, Ex- } \\
\text { Comissário da Ordem } 3^{\text {a }}\end{array}$ \\
\hline Manoel de São Miguel & Europa & 1728 & 1780 & $\begin{array}{l}\text { Pregador, Ex-Comissário da } \\
\text { Ordem } 3^{\text {a }}\end{array}$ \\
\hline Luiz do Sacramento & Europa & 1730 & 1784 & $\begin{array}{l}\text { Ex-Definidor, Ex-Guardião, } \\
\text { Pregador }\end{array}$ \\
\hline José de São Joaquim & Bahia & 1754 & 1788 & $\begin{array}{l}\text { Ex-Definidor, Ex-Guardião, } \\
\text { Pregador, Ex-Comissário da } \\
\text { Ordem } 3^{\text {a }}\end{array}$ \\
\hline Paschoal de São José & Bahia & 1733 & 1788 & Ex-Guardião, Pregador \\
\hline João de São Caetano & Bahia & 1763 & 1791 & Missionário, Confessor \\
\hline $\begin{array}{l}\text { Francisco da Conceição } \\
\text { Solano }\end{array}$ & Pernambuco & 1756 & 1792 & Pregador \\
\hline $\begin{array}{l}\text { Manoel da Conceição } \\
\text { Rocha }\end{array}$ & Europa & 1741 & 1794 & $\begin{array}{l}\text { Ex-Definidor, Ex-Guardião, } \\
\text { Pregador, Ex-Comissário da } \\
\text { Ordem 3a }\end{array}$ \\
\hline Francisco das Chagas & Europa & 1745 & 1795 & $\begin{array}{l}\text { Ex-Definidor, Ex-Guardião, } \\
\text { Pregador }\end{array}$ \\
\hline Custódio da Purificação & Europa & 1760 & 1795 & Ex-Guardião, Pregador \\
\hline $\begin{array}{l}\text { Francisco de Santa } \\
\text { Margarida }\end{array}$ & Pernambuco & 1754 & 1797 & $\begin{array}{l}\text { Confessor, Ex-Comissário da } \\
\text { Ordem } 3^{\text {a }}\end{array}$ \\
\hline José de São Boaventura & Bahia & 1754 & 1798 & Ex-Guardião, Pregador \\
\hline Antônio do Paraíso & Nacional & 1734 & 1798 & Pregador \\
\hline Jerônimo de Santa Quitéria & Bahia & 1758 & 1804 & Pregador \\
\hline Luciano das Neves & Bahia & 1748 & 1807 & Ex-Guardião, Pregador \\
\hline
\end{tabular}

Fonte: dados da documentação consultada, organizados pela autora.

Desse modo, se pode afirmar que dentre os 305 frades professos na Província em 1779, ao menos dezesseis deles ou já exerciam a função de mestre de gramática ou viriam a exercê-la até sua morte. Um detalhe interessante é que todos eles também foram pregadores ou confessores, funções para as quais se exigia um profundo conhecimento teológico e dogmático, como se pode conferir nos Estatutos de 1709:

Declaramos que o Irmaõ Ministro póde instituir Confessores de Frades aos Religiosos Sacerdotes, que tiverem trinta annos de idade, \& quinze de habito; porém sendo Prégadores, ou Presidentes, ou não havendo em algữa caza Sacerdotes, que tenham a ditta idade, os poderá o Irmão Ministro instituir, tendo menos; com tanto que todos os dittos Confessores sejam primeyro examinados por dous

26 AHU_ACL_CU_015, Cx. 135, D. 10107, Anexos 1 e 2; APFR, Pacote 20, Livro III, 1.

27 O guardião é o superior de um convento, com direito a voto nas eleições dos capítulos provinciais. (WILLEKE, 1956, p. 258). 
Religiosos doutos dos casos reservados, censuras Ecclesiasticas, Sacramentos da Igreja, \& preceytos Divinos, \& conste por testemunho dos dittos Examinadores sufficiencia, que nestas materias tem; \& os que sem preceder semelhante exame forem instituidos, não sejam havidos por idoneos Confessores. (ESTATUTOS, 1709, p. 39).

Os irmãos pregadores também tinham de passar por exame de suficiência nos mesmos moldes, como fica claro no modelo de patente de pregador ao final dos Estatutos de 1709 (ESTATUTOS, 1709, p. 219). É bom também lembrar aqui quais eram as determinações a respeito dos mestres de gramática:

Para que os Estudantes, q haõ de ir à Filosofia, sejam bons Grammaticos, ordenamos que no Convento de nosso Padre S. Francisco da Cidade da Paraiba haja estudo de Grammatica, pois he o fundamento de todas as mais sciencias; para o qual elegerà o Irmaõ Ministro quando for em visita dès, ou doze Religiosos, que vir tem genio, \& habilidade para as mais sciencias; \& para Mestre do ditto estudo de Grammatica escolherá de toda a Provincia o Religioso, que estiver mais bem visto nella, para que da sua explicaçaõ se aproveytem os discipulos; ao qual Mestre izentamos de todo o Coro \& obrigações do Convento. (ESTATUTOS, 1709, p. 31).

No caso dos lentes de Filosofia, além dos exames feitos por meio de aula ministrada na presença dos mestres avaliadores também era realizada, numa segunda etapa, uma eleição para escolha do mais capaz dentre os candidatos à função:

O Lente de Filosofia deve ter scencia bastãte para defender a doutrina, que ha de ensinar, \& assim nenhum deve subir à cadeyra sem que seja primeyro examinado se he, ou não he capaz de exercer o officio. [...]

[...] mandará o Irmaõ Ministro convocar para o dia sinalado [...] os Religiosos, que forem mais idoneos, assim nas letras, como na virtude, para q se opponham à Leytura [...]; mandará também convocar os Mestres, que houver na Provincia [...] aquem os oppositores daraõ os pontos, sobre q lhe haó de argumentar hum dia antes para terem tempo de os verem.

No dia do exame na presença do Irmaõ Ministro, \& seu Diffinitorio argumentaraõ os Mestres, \& Passantes que houver, aos que se oppuzerem à Cadeyra; \& feyto o exame, será eleyto Mestre, \& Lěte de Filosofia dos oppositores o mais sciente, a qual eleyçaõ será feyta pelos Mestres de Theologia, que Ihe argumentaram, \& se acharam presentes ao exame, por votos de cedulas fechadas, como em qualquer outra eleyçaõ, \& o que naõ levar a Cadeyra pela opposiçaõ referida, não Ihe servirá a Leytura de preminencia alguma.

(ESTATUTOS, 1709, p. 33).

Quanto aos lentes de Teologia, a decisão estava restrita ao Ministro Geral, mas as exigências não eram mais brandas por isso:

A Eleyção de Lente de Theologia pertence ao Irmão Ministro com o seu Deffinitorio, porem se por alguma causa vagar algum Lĕte de Theologia, o Irmaõ Ministro por si só poderá pór outro em seu lugar. [...]

Não se elegerà Lente de Theologia, que não tenha lido [lecionado] primeyro tres annos filosofia com approvaçaõ da Provincia, \& utilidade de seus discipulos.

(ESTATUTOS, 1709, p. 33).

Considerando-se a instrução como um todo, Tania Iglesias destaca que, ao contrário do que se difundiu durante um bom tempo na historiografia específica sobre os franciscanos em nosso país, eles tiveram sim uma forte atuação nela no Brasil colonial, não se atendo apenas à catequese: 
Diferentemente do que se tornou senso comum, a educação Colonial não se tratou apenas de iniciação aos preceitos cristãos ou catequese. Os frades estabeleceram e conservaram aqui as seguintes modalidades de ensino: Escola de primeiras letras em regime de internatos para indígenas, Escola de Primeiras letras em regime de externato para leigos, Escola Secundária Interclassista para a elite Colonial e para a formação na Ordem, Ensino Superior em regime de internato para formação na Ordem e Ensino Superior Misto em regime de externato para a elite Colonial e para a formação também do clero secular. (IGLESIAS, 2010, p. 342).

Realmente, no que se refere às aulas de gramática, se consultando o Novo Orbe Seráfico e também as Atas Capitulares é possível recuar a instalação de aulas de primeiras letras ou escolas de gramática pelos franciscanos a 1650, em Sergipe Del Rey (ATAS, 1970, p. 98). Muitas dessas aulas eram ministradas extramuros, a bem do povo e sem despesa alguma aos atendidos por tais atividades, como aparece explicitamente em alguns documentos (WILLEKE, 1956, p. 301). Quanto às classes elementares, Miranda salienta que a documentação compulsada por Fr. Willeke nos Arquivos da Província de Santo Antônio, no Recife, apresenta certas discrepâncias em relação às datas registradas por Fr. Jaboatão em seu Novo Orbe. Contudo, foi possível identificar a existência de cursos regulares, intra e extramuros e praticamente ininterruptos, nas casas da Paraíba (1709 - C. 1790/1795); de Cairu (1718-1780) e Conde (1763-1771), na Bahia; São Cristóvão (17191785), em Sergipe; Penedo (1718-1782), Vila de Alagoas (1718-1780), Sirinhaém (1719) e Ipojuca (1719-1780), em Pernambuco (ATAS, 1970; JABOATAM, 1858, passim.; MIRANDA, 1969, p. 200-202).

Há, portanto, uma permanência de tais classes, especialmente de gramática, mantidas pelos franciscanos, mesmo após a determinação metropolitana, em 1759, de se substituir todas as aulas de instrução elementar ministradas por religiosos por classes conduzidas por docentes civis, os chamados professores-régios, devidamente chancelados pelo poder colonial através dos diretores de estudos.

Mesmo não cumprindo imediatamente as rígidas determinações da Coroa, como atesta o registro - principalmente nas Atas Capitulares, mas também em outros documentos esparsos do Arquivo Histórico Ultramarino - do funcionamento de aulas de gramática nos conventos por ainda mais de vinte anos após a reforma pombalina, o ministro provincial de então, Frei Antonio de Santa Isabel, fez o teor do alvará régio chegar ao conhecimento de todos os guardiães, frades, noviços e irmãos leigos dos conventos da Bahia, de Pernambuco e da Paraíba ainda no primeiro semestre de 1760 , como atesta a circular transcrita por Fr. Venâncio Willeke a partir de relatório do historiador Pereira da Costa para o governo provincial pernambucano, publicado em 1886:

Senhor Guardião.

Por alvará de sua Magestade que Deus guarde se prohibiram os estudos de grammatica neste Estado da Bahia e Capitania de Pernambuco. Este foi o motivo que tive para na mesma Congregação não nomear mestres para os conventos desta Província, como sempre se costumou e como não sei se chegou a noticia do dito alvará a este sobredito convento o aviso para de hoje em diante não consinta V. Caridade a continuação da classe de grammatica para não incorrermos nas penas que no dito alvará se declaram contra os transgressores e se o povo reclamar, Ihe dirá V. C. recorram por via da Camara onde a houve e por meio da Juiz Ordinario onde não houver Camara, aos diretores de estudos e quando se alcance licença para continuar o estudo e na mesma forma que até agora ensinávamos avise V. C. ao mestre que até o presente o era desse convento que continue o seu ministerio com advertencia porém, que se na licença concedida disserem os diretores que seja 
o mestre examinado por esta ou aquela pessoa não consinta V. C. tal, pois aos mestres de grammatica dos conventos desta Provincia lhes basta o exame e aprovação dos nossos prelados maiores. No convento de Serinhaem concedida a licença na forma sobredita, ensinará grammatica pro ínterim o Ir. Pregador e Presidente do convento Frei Mariano de Sto. Antonio. Esta carta mandará V. C. ler em plena comunidade para que a todos conste a obediencia que tem esta província ás ordens de S. Magestade e V. C. a remeterá ao convento mais vizinho para ir correndo todos os conventos até o da Parahiba inclusive assinando-a todos os guardiães e do último convento nos será remetida. Convento de N. Padre S. Francisco da Cidade da Bahia, 25 de Maio de 1760. Frei Antônio de Sta. Izabel, Ministro Provincial. (WILLEKE, 1956, p. 341).

A bem da verdade, a determinação de Pombal, fruto de um longo processo de reestruturação da instrução nas terras sob o controle da Coroa lusa e consolidada com a publicação do alvará que proibiu as aulas públicas ministradas pelos religiosos em 1759 (VILLALTA; MORAIS; MARTINS, 2015, p. 456), só começou a ter efeitos reais sobre a atuação franciscana na América portuguesa, notadamente nas Capitanias do Norte do Estado do Brasil, a partir de 1785, ano em que, segundo Maria do Carmo Miranda (1969, p. 201) cessou de fato o funcionamento das aulas de gramática para o público extramuros entre os franciscanos, e daí até o advento do Império o que se viu foi um declínio acentuado inclusive do número de noviços e de frades dedicados à docência mesmo intramuros. Ao se entrar no Oitocentos, a Pedagogia Franciscana parecia estar ameaçada, assim como a própria renovação da vocação seráfica, em diversos dos conventos mantidos pela ordem na faixa litorânea compreendida entre o Recôncavo Baiano e a foz do Rio Paraíba.

Por meio dos anexos à carta enviada pelo provincial franciscano a $D$. Maria I em 1779, que trazem duas relações com todos os professos da Província, se pode chegar a outra constatação, a de que àquela época os conventos seráficos já padeciam do envelhecimento de seus frades, algo que se percebe claramente ao organizar as informações constantes na documentação: quase $40 \%$ dos irmãos tinham mais de 30 anos de vida religiosa, o que pode significar indivíduos numa faixa etária acima dos $45 / 50$ anos e, desses, praticamente a metade certamente já devia ter ultrapassado os 60 anos de idade ou estar prestes a tornar-se sexagenária, considerando que seus noviciados tenham se iniciado por volta de seus 15 a 20 anos de idade.

Ao observar os dados da Tabela 02, outro detalhe que salta aos olhos é que ao menos desde 1764 nenhum noviço professara os votos e entrara para a Ordem na Província. Em 1779 já fazia dezesseis anos que não ocorria renovação de seus quadros, o único horizonte era a conclusão da formação dos vinte e seis noviços estabelecidos em Igarassu e Paraguaçu, que após três anos nessas casas ainda deveriam mudar-se para Olinda ou Salvador a fim de enfrentar, no mínimo, mais três a seis anos de estudos superiores de Teologia e Filosofia (ATAS, 1970, p. 192; MUELLER, 1956, p. 49-50), a não ser no caso daqueles que não tivessem condição de fazê-lo e fossem destinados a ordenarse como irmãos leigos. A perspectiva para os seráficos naquele momento, portanto, não era das melhores: a maior parte dos frades da Província não devia ter mais compleição física para dar conta de tantas atividades, especialmente aquelas exercidas fora dos conventos, e não entravam irmãos jovens na congregação, um dilema aparentemente intransponível graças aos ditames da Coroa portuguesa. 
Tabela 02 - Tempo de hábito dos frades da província franciscana de Santo Antônio do Brasil - $1779^{28}$

\begin{tabular}{l|c|c|c|c|c|c}
\hline \multicolumn{1}{c|}{ ANOS } & NACIONAIS & $\%$ & EUROPEUS & $\%$ & TOTAL & $\%$ \\
\hline mais de 60 & 4 & 1,31 & 1 & 0,32 & 5 & 1,63 \\
\hline de 50 a 59 & 12 & 3,93 & 12 & 3,93 & 24 & 7,86 \\
\hline de 40 a 49 & 20 & 6,55 & 20 & 6,55 & 40 & 13,11 \\
\hline de 30 a 39 & 27 & 8,85 & 25 & 8,19 & 52 & 17,04 \\
\hline de 20 a 29 & 85 & 27,86 & 45 & 14,75 & 130 & 42,62 \\
\hline de 16 a 19 & 36 & 11,80 & 16 & 5,24 & 52 & 17,04 \\
\hline TOTAL & $\mathbf{1 8 6}$ & $\mathbf{6 0 , 9 8}$ & $\mathbf{1 1 9}$ & $\mathbf{3 9 , 0 2}$ & $\mathbf{3 0 5}$ & $\mathbf{1 0 0}$ \\
\hline
\end{tabular}

Fonte: dados da documentação consultada, organizados pela autora.

A Tabela 03 permite também se inferir outro detalhe instigante: enquanto apenas quatro nacionais preparavam-se para seguir a vida religiosa na Província de Santo Antônio do Brasil, vinte e dois jovens nascidos no Reino ou nas llhas pretendiam vestir o hábito de Assis na América portuguesa e não num dos inúmeros conventos da Ordem espalhados no Reino ou nas possessões lusas d'além-mar. Talvez esse seja um aspecto que mereça mais atenção em estudos futuros.

Tabela 03 - Origem dos noviços em formação na província franciscana de Santo Antônio do Brasil - $1779^{29}$

\begin{tabular}{|c|c|c|c|c|c|c|c|c|c|}
\hline \multirow{3}{*}{ CONVENTO } & \multicolumn{8}{|c|}{ BISPADOS / ARCEBISPADOS } & \multirow{3}{*}{ TOTAL } \\
\hline & \multicolumn{2}{|c|}{ BRASIL } & \multicolumn{6}{|c|}{ REINO / ILHAS } & \\
\hline & Pernambuco & Bahia & Braga & Porto & Lamego & Coimbra & Penafiel & $\begin{array}{l}\text { Angra do } \\
\text { Heroísmo }\end{array}$ & \\
\hline Igarassu & 1 & 1 & 1 & 6 & 2 & 1 & - & - & 12 \\
\hline Paraguaçu & 1 & 1 & 4 & 3 & - & 1 & 2 & 2 & 14 \\
\hline TOTAL & 2 & 2 & 5 & 9 & 2 & 2 & 2 & 2 & 26 \\
\hline
\end{tabular}

Fonte: dados da documentação consultada, organizados pela autora.

O fato é que o esvaziamento dos conventos na América portuguesa, não apenas franciscanos mas também de outras ordens religiosas, se agravara na segunda metade do Setecentos, como consequência direta do Decreto Régio emitido em 30 de janeiro de 1764 por $\mathrm{D}$. José $\mathrm{I}^{30}$, que reforçou restrições anteriores e vedou a todos os conventos, mosteiros e seminários localizados nas terras sob a Coroa lusa de receberem postulantes, salvo no caso de permissões específicas. Essa proibição foi aprofundada através de um Aviso Régio datado de 26 de maio de $1769^{31}$, de alcance mais amplo. De certa forma, o Império

${ }^{28} \mathrm{AHU}$ ACL_CU_015, Cx. 135, D. 10107. Anexos 1 e 2.

${ }^{29}$ AHU_ACL_CU_015, Cx. 135, D. 10107. Anexo 4.

30 O Decreto Régio de 30 de janeiro de 1764 vedou a Província de Santo Antônio do Brasil de receber noviços por catorze anos a partir daquela data. (MIRANDA, 1969, p. 92; BELO, 2011, v. 2, p. 24).

${ }^{31}$ Os governos de D. José I e de D. Maria I constantemente tentaram, por meio de diversas medidas, controlar 
brasileiro manteve tal postura após a Independência, de maneira velada, e no caso dos franciscanos houve algumas poucas permissões para jovens postulantes ao noviciado. A entrada de noviços na Província franciscana praticamente deixou de existir em 1845, quando D. Pedro II, motivado por querelas com Roma envolvendo a instituição do Padroado, emitiu um decreto vedando a admissão de jovens na vida religiosa em todos os conventos, mosteiros e seminários brasileiros. No caso da Província de Santo Antônio do Brasil, a chegada da República em 1889 encontrou apenas oito frades em suas casas conventuais, com várias delas abandonadas por completo. (MIRANDA, 1969, p. 92).

\section{A formação de noviços: aulas intramuros}

Nos Estatutos da Província de Santo Antônio do Brasil é possível identificar bem claramente a preocupação que havia na congregação com a formação de seus noviços. Lá estão seis capítulos dedicados a temas relativos à instrução no espaço conventual, a saber: "Capitulo XIII. Da caza em que ha de haver Estudo de Grammatica, \& do Mestre, \& Estudãtes do dito Estudo"; "Capitulo XIV. Das cazas em que ha de haver estudos de Filosofia, \& Theologia"; "Capitulo XV. Dos Lentes de Filosofia"; "Capitulo XVI. Dos Lentes de Theologia"; "Capitulo XVII. Dos Collegiaes"; "Capitulo XVIII. Da ordem escolastica". (ESTATUTOS, 1709, p. 31-38).

O detalhamento das diretrizes para a prática pedagógica intramuros nesses capítulos em particular permite se perceber a maneira como ela se estruturava e qual era o encadeamento idealizado para a formação dos noviços. O primeiro conhecimento necessário aos jovens que desejavam abraçar a vida franciscana era o de gramática. Ler e compreender as Escrituras, para depois ser capaz de reproduzi-las e ensinar os dogmas e a doutrina aos fiéis era o núcleo fulcral da ação franciscana. Por isso mesmo, os ditos estudos gramaticais, dedicados ao Latim, precediam os de Filosofia e estes aos de Teologia. O próprio cotidiano dos estudantes deveria seguir uma rotina bem rígida, que incluía seis horas diárias de estudos, distribuídas pela manhã, tarde e noite, sob vigilância constante de todos os frades professos residentes nas casas conventuais, especialmente aqueles que exerciam sua guardania e sua presidência, bem como os mestres. A vida desses estudantes também era marcada por castigos físicos e por uma completa submissão a seus professores:

Os Estudantes de Grammatica iraõ para o Estudo ás sette horas da manhã, \& sahiraõ às nove, \& de tarde iraõ para o Estudo á hũa hora, \& sahiraõ às tres; e estudaraõ de noyte das oyto horas atè as dés [...].

[...] O Irmaõ Guardiaõ terá cuydado de cõprar, todos os livros classicos, que forem necessarios para os Estudantes, \& de lhe dar todo o mais necessario de papel, tinta, \& tinteyros para fazerem themas, \& sentidos, como tambem candeas, \& azeyte para estudarem de noyte; o que farão com portas abertas na mesma fórma dos Estudantes de Filosofia, \& o Mestre, \& Presidente, \& Giardiaõ do Convento teraõ

e mesmo impedir o crescimento das ordens conventuais e monásticas no Reino e no além-mar, com vistas a tolher o fortalecimento econômico destas congregações e sua consequente e possível autonomia em relação à Coroa e à instituição do Padroado. Uma das medidas mais comuns foi a limitação ou veto à admissão de noviços, presentes em diversos decretos, Proibições e Avisos Régios emitidos entre 1762 e 1790 (CONDE, 2002/2003, p. 164; ANDRADE, 1981, v. 1, p. 570). Neste longo período, muitas vezes as casas religiosas conseguiam permissões temporárias para admitir postulantes ao noviciado. Segundo Maria do Carmo Miranda, a Província de Santo Antônio do Brasil, durante a segunda metade do Setecentos, teve seus pedidos de entrada de noviços atendidos pela Coroa portuguesa apenas por três vezes até o ano de 1800. (MIRANDA, 1969, p. 92). 
cuydado de os vigiar se estudam, \& achandoos descuydados, os castigue rigorosamente.

$[\ldots]$

O Mestre da Grammatica terá todo o poder sobre seus discipulos para os castigar pela falta de suas lições, \& descuydos de seu estudo; \& assim os poderà açoutar, \& mandar açoutar, \& penitenciar conforme o merecerem, ao que o Guardiaõ, \& Presidente não poraõ duvida, nem estorvaraõ o castigo, que seu Mestre lhes der, \& mandar dar.

$[\ldots]$

O Estudante de Grammatica, que perder o respeyto a seu Mestre de Grammatica, ou se naõ, quizer despir por seu mandado, o Irmaõ Guardiaõ o penitenciará com as disciplinas, q the parecer, \& fará aviso ao Irmaõ Ministro, para que disponha outro mayor castigo, segundo Deos melhor lhe parecer.

(ESTATUTOS, 1709, p. 31-32)

De fato, o convento da Paraíba já se mostrava com destaque no campo da instrução intramuros, pois nele foram instaladas, como se viu acima, as aulas de gramática latina, 0 primeiro curso que os postulantes recém-admitidos à ordem como noviços deveriam fazer sob os auspícios dos seráficos, a fim de se preparar para os estudos iniciais de filosofia e teologia, a serem desenvolvidos nos conventos de Paraguaçu, na Bahia, ou de Igarassu, em Pernambuco (ATAS, 1970, p. 215). Já os estudos superiores e finais para a formação dos noviços, onde aprofundariam seus conhecimentos teológicos e filosóficos antes de realizarem seus votos perpétuos, esses seriam realizados nas casas de Salvador e de Olinda, que juntas à de Recife se constituíam como os três maiores conventos da província franciscana. (ESTATUTOS, 1709, p. 32).

O fim das aulas de gramática para os jovens religiosos, ao menos no convento franciscano da Paraíba, parece ter sido condicionado pelo esvaziamento da ordem ao longo da segunda metade do século XVIII. Isso fica claro em uma das determinações da congregação celebrada no convento de Salvador em 03 de maio de 1795:

[...] determinou-se, que visto não haver já nesta Província classe de Gramatica, como antigamente houve no nosso Convento da Paraíba, para instruçaõ e erudiçaõ dos nossos Iros. Choristas ou Noviços em aqueles Conventos, que houvesse Chorista ou Noviços [...]. (ATAS, 1970, p. 142).

Como já foi referido, apenas dezesseis anos antes, em 1779, na Relação enviada à Coroa pelo provincial, se registrava somente vinte e seis noviços em toda a Província franciscana, estando doze na Bahia e catorze em Pernambuco, com o detalhe de que três postulantes tiveram suas patentes caçadas pelo visitador assim que este tomou ciência das então recentes proibições régias quanto ao ingresso de noviços nas ordens religiosas ${ }^{32}$.

\section{Os franciscanos na Paraíba e as aulas extramuros}

Algo que não pode ser ignorado, ao se começar a buscar indícios sobre a prática pedagógica dos frades menores fora dos muros conventuais, são dois documentos encaminhados a Lisboa pelos moradores da Paraíba, mais de uma década após o início da reforma pombalina, solicitando o serviço dos seráficos para remediar a situação de penúria e abandono das aulas de gramática naquela capitania. A reivindicação dos paraibanos é bem clara:

${ }^{32}$ AHU_ACL_CU_015, Cx. 135, D. 10107. 
Snr.

A indigencia q experimentaõ os Naturaes moradores desta Cidade da Paraiba de Professorez de Letras, para a Educasão de seos filhos, nos comove implorar a V. $\mathrm{Mg}^{\mathrm{e}}$. o providencie remedio desse necessario bem [...] e como a nessa mesma Cide tres Religioěs de S. Bento, S. Francisco, e Carmo, [...] podem os Religiosos de qualquer dessas exercer esse grande beneficio sendolhes assim decretado pela indefecivel providensia de V. Mage. [...]. 30 de abril de 1772, Manoel de Barroz Silva, Escrvao. da Camara, q o escrevi.

Bento Luiz da Gama Mathias Leal de Lemos

Franco Soares Neiva

Domgos Joze da Rocha ${ }^{33}$

No Setecentos, a burocracia do Conselho Ultramarino parecia infindável, além de pouco se importar com uma solução rápida ao problema da falta de professores para ministrar aulas aos filhos dos colonos. A sugestão pelo emprego dos religiosos para a tarefa, indicando a disponibilidade não apenas dos franciscanos, mas também de beneditinos e carmelitas instalados na cabeça da Capitania, só parece servir para dar rumo aos trâmites kafkianos presentes no despacho anotado à margem da carta, já que se indica que ela seja reenviada pelos oficiais paraibanos à Real Mesa Censória:

Esta reprezentaçaõ p. ${ }^{\text {a }}$ ser empreterivelmte feita, e de conformidade do q. S. Magde. determinou no Alvará de 3 de junho de 1772, devem-na os Offaes da Cam ${ }^{\text {ra }}$ dirigir á Real Meza Censoria.

Respondase a Cam ra na conformide. da Resposta do Procurador da Fazenda, 13 de julho de $1772 .^{34}$

A falta de mestres de gramática para os jovens paraibanos parece ter se arrastado durante um bom tempo ${ }^{35}$ em fins do século XVIII, como aponta o ofício enviado pelo governador da Capitania, brigadeiro Jerônimo José de Melo e Castro, a seu irmão, o secretário de Estado de Marinha e Ultramar, Martinho de Melo e Castro, mais de quatro anos após a carta dos oficiais da Câmara, ainda se queixando pela permanência do problema de vacância da função, apesar dos constantes pedidos feitos ao Diretor de Estudos de Recife, já que à época a Capitania da Paraíba estava anexada à de Pernambuco. No documento aparece também a indicação de sua preferência pelos franciscanos, por estes já exercerem a docência pública em três povoações diferentes onde existiam conventos seráficos:

Illmo. Exmo. Snr.

Depois q se expulsaram os chamados Jesuitas ficou esta Cide. e Capitania sem Mes de Gramatica, e sevai toda a mocide arcando sem estudos, e brevemente se redusira tudo a huma sensivel ignorancia.

Ja expus e dei Requerimento a $S \mathrm{Ma}^{\mathrm{ge}}$. que mandou procurase a providencia do Diretor dos Estudos que ate este ponto a nao deu.

Pareciame justo que os Pes. Franciscanos fossem ensinando Gramatica assim como a estam praticando nas suaz Cazas do Penedo e de Igarassu e na $C^{\text {de }}$. de Sergipe onde os Religiosos sao Mes. publicos de Gramatica.

M. Gde. a V. Sa. Par. 6 de Novembro de $1776 .{ }^{36}$

${ }^{33} \mathrm{AHU}$ ACL_CU_014, Cx. 25, D. 1925.

${ }^{34}$ AHU_ACL_CU_014, Cx. 25, D. 1925.

${ }^{35}$ As solicitações paraibanas só foram atendidas em 1782, por meio de um Aviso do Secretário de Marinha e Ultramar à Mesa Censória, para que se providenciasse um mestre de gramática em atendimento aos pedidos do governo da capitania, insistentes desde 1765 (AHU_ACL_CU_014, Cx. 28, D. 2109).

${ }^{36}$ AHU_ACL_CU_014, Cx. 25, D. 1977. Grifos meus. 
Pelo ofício fica claro que os franciscanos, apesar das restrições impostas pelo alvará régio de 1759 , de fato ainda atuavam, naquele momento, como professores extramuros, já que atendiam às aulas de gramática como "mestres públicos" nas localidades de Penedo e Igarassu em Pernambuco, e Conde, na Bahia, como informa o brigadeiro. De fato, seria necessário um trabalho de pesquisa mais aprofundado, cruzando a documentação do Arquivo Histórico Ultramarino com a do Arquivo Provincial Franciscano do Recife para que se possa perceber, de maneira mais completa, qual era, realmente, o alcance da atuação dos seráficos como professores entre os leigos e como se estruturava e engendrava sua pedagogia no trato com os fiéis nessas classes de gramática. Destaquese que no caso da Paraíba, a Relação de 1779 assinalava a existência de 21 frades no convento franciscano ${ }^{37}$.

Em sua dissertação de mestrado sobre a pedagogia moral franciscana nos conventos de Alagoas, Mônica Santos destaca a ligação direta da atividade instrucional à prática religiosa dos religiosos de Assis (SANTOS, 2007, p. 114-115). Creio mesmo que esta afirmação pode ser estendida aos outros conventos da Ordem dos Frades Menores erguidos no litoral das outras capitanias próximas onde, até o que se sabe no momento, o funcionamento das aulas de primeiras letras seguiam os mesmos moldes daquilo que ocorria nos outros cenóbios seráficos.

Mônica Santos também destaca que, apesar do discurso sobre a gratuidade das aulas ministradas pelos frades franciscanos, é possível associar sua oferta à presunção de retribuição da Coroa aos religiosos, por meio de esmolas, conforme relatado por Fr. Jaboatão em seu Novo Orbe Seráfico (SANTOS, 2007, p. 116; JABOATAM, 1858). Mostrase aí, obviamente, o caráter prático de tais atividades de instrução para a manutenção das casas franciscanas em sua missão catequética na América portuguesa.

\section{As Livrarias Conventuais entre os Franciscanos e a Livraria Paraibana}

As livrarias ${ }^{38}$ estabelecidas junto às sés ou casas religiosas se constituíam segundo Maria de Lourdes Ganho ao referir-se à conjuntura portuguesa - em espaços cujo acervo ditava a qualidade da atuação dos professores, dos quais dependia também a da instrução em terras sob o poder da Coroa lusa. Isso se dava pelo fato de o acervo dessas bibliotecas não se restringir às obras teológicas ou doutrinárias, mas sempre abarcar "também outras, de caráter escolar e pedagógico, possibilitando o estudo da gramática, da retórica, da música, aritmética, etc." (GANHO, 1994, p. 141).

Não se pode deixar de assinalar que a questão pedagógica entre os frades menores estava, certamente, ligada a uma característica de suas casas conventuais na América portuguesa: a vinculação obrigatória, por meio de determinação explícita nos Estatutos provinciais, de uma livraria a cada cenóbio da ordem erguido na faixa litorânea entre a Bahia e a Paraíba, segundo os cânones arquitetônicos da hoje chamada Escola

\footnotetext{
37 AHU ACL CU 015, Cx. 135, D. 10107. Anexo 3.

38 No mundo de língua portuguesa, até a primeira metade do século XIX este termo era usado como sinônimo de "biblioteca" e definia o espaço dedicado à guarda dos livros e sua consulta pelos leitores, inicialmente junto às Sés e catedrais, e depois em conventos, mosteiros, seminários, colégios e universidades. Também era utilizado para nomear as coleções particulares. A expressão aparece definida como "Lugar onde estão muitos livros em estantes" e "Bibliotheca" no dicionário do Pe. Raphael Bluteau, publicado pelo Colégio dos Jesuítas em Coimbra pela primeira vez em 1712 e republicado em diversas ocasiões ao longo de todo o século XVIII. (BLUTEAU, v. 5, 1716, p. 163).
} 
Franciscana do Nordeste ${ }^{39}$ :

Todas as nossas cazas tenham livrarias, de que haverá inventario, \& dos livros que nelas estão, dará conta o q assistir na livraria, para o que terá o tal Religioso a chave della, \& o Guardião terá cuydado de mandar concertar os livros, para que senão percam; \& se indo o Irmão Ministro, ou Visitador visitar a livraria de algum Convento, achar alguns livros rotos, desencardenados, \& sem capas, os mandará logo concertar, \& suspenderá o Guardião da caza por dous mezes em pena de os não ter mandado concertar antes que se visitasse o Convento. (ESTATUTOS, 1709, p. 137).

Também há, nesses mesmos Estatutos provinciais, determinações sobre o trato, a guarda e o uso dos livros no interior das casas religiosas e também sobre a compra de certas obras para uso nas aulas ministradas pelos frades mestres. Fica ainda mais clara a importância que os livros e bibliotecas tinham na vida conventual quando se constata que a normatização provincial traz todo um capítulo dedicado ao tema, intitulado "Das livrarias \& livros". Nele se dispõe sobre a organização e gestão da livraria e o uso e empréstimo dos livros aos frades e noviços, além das políticas de conservação e aquisição de novas obras para o acervo:

E para que as livrarias se provejam de livros com suavidade, ordenamos que cada Guardião em o termo de sua Guardania de anno \& meyo mãde buscar a Portugal seis tomos de livros dos que forem mais necessarios na livraria do seu Convento, começando primeiro a prover a livraria dos Expositores da sagrada Escritura, e assim iraõ os mais Guardiães provendo as livrarias dos mais livros, assim de Moral, como de predica, mandando cada hum buscar a conta de seis tomos, como asima ordenamos; \& se o Guardião continuar tres anos em um Convento, será obrigado a mandar buscar doze tomos em os tres anos, \& Guardião do Convento da Cidade da Bahia, \& o da Cidade de Olinda, dos livros que mandem buscar, serão tambem alguns classicos de Filosofia, \& Theologia especulativa, para que os Mestres destas duas cazas de estudo tenham livros necessarios das faculdades, que ensinarem, \& o Guardião que não prover em o termo de sua Guardiania de anno \& meyo a sua livraria com os sobreditos seis tomos de livros, será privado de voz activa, \& passiva por tres annos. (ESTATUTOS, 1709, p. 137-138).

O cuidado com a guarda, conservação e circulação dos volumes de suas livrarias denota a importância atribuída pelos franciscanos aos livros. Como os objetivos primordiais da Ordem eram a missionação e a catequese, a formação dos frades passava, obviamente, pelos fundamentos teológicos e doutrinários presentes nos volumes adquiridos para essas livrarias e utilizados nas aulas conventuais.

A circulação de obras entre as livrarias, aliás, apesar de expressamente proibida nos Estatutos, parece sempre ter sido uma realidade entre as casas seráficas. É o que nos mostra o documento datado de 1648, em plena invasão holandesa, e no qual, ao quantificar o acervo da livraria conventual pernambucana de Ipojuca, situada a 50 quilômetros ao sul do Recife, o Visitador, Fr. Jácome da Purificação, assinala que nela se encontravam onze volumes pertencentes à casa paraibana sem, contudo, discriminá-los:

Acharam-se nesta livraria 190 livros, digo 200 livros com os pequenos. Entre os quais as glosas ordinárias entram em seis volumes, as partes de sagrada teologia

\footnotetext{
${ }^{39}$ Expressão cunhada por Germain Bazin, ex-diretor do Museu do Louvre, quando da elaboração de sua tese de doutorado tratando da arquitetura religiosa barroca no Brasil, em fins da década de 1940. Para maiores detalhes, ver: BAZIN, 1983, v. 1, p. 137-156; FERNANDES, 2013, p. 281-307.
} 
em cinco volumes, as obras de St.o Agostino em cinco volumes, as obras de São Bernardo em dois, o Incógnito, as obras de Moral de Diana em dois volumes grandes. Dêstes livros consta esta livraria do convento de St.o Antônio de Ipojuca. Da casa da Paraíba estão nesta onze livros; os mais dêste convento como dos mais se perderam com os sucessos da guerra. E por verdade, me assino hoje aos 24 dias do mês de abril de 1648. (Assi) Frei Jácome da Purificação, comissário visitador. Frei Masseu de S. Francisco, secretário. (WILLEKE, 1956, p. 321-322, grifos meus).

Ora, Isabel Drumond Braga afirma que "tanto no século XVII quanto na centúria seguinte, a maior parte dos possuidores de livros, que indicaram o número de volumes, deu conta de livrarias que poucas vezes ultrapassaram a centúria de títulos" (BRAGA, 2014, p. 106). Isso posto, a livraria seráfica de Ipojuca não pode ser considerada pequena para a época - meados do século XVII - mas, no entanto, recorria ao empréstimo de obras de suas congêneres franciscanas mais próximas, chegando a agregar a seu acervo volumes da livraria do Convento de Santo Antônio da cidade da Paraíba, situado a mais de $170 \mathrm{Km}$ de distância, e isso numa época de transporte penoso e demorado, fosse ele realizado no lombo de montarias ou por via marítima/ fluvial.

No mundo ibero-americano, outras livrarias franciscanas dos séculos XVII e XVIII tiveram mais sorte do que as da Província de Santo Antônio do Brasil, possibilitando estudos sobre as práticas pedagógicas, de leitura e a circulação ideias entre os frades (CAMPOS, 2013; LOIZAGA, 2008; XAVIER, 2011).

No Brasil imperial, já no século XIX, por exemplo, diversos viajantes estrangeiros se referem à biblioteca do convento franciscano do Rio de Janeiro que, por volta de 1850 , teria cerca de 3.000 volumes (SILVA, 2010, p. 75). Em 1876, devido ao abandono em que se encontrava o convento recifense, o acervo de sua livraria estava em tão mal estado que parte de seus volumes foi queimada. O restante de seu acervo, cerca de 1.600 volumes, apenas dez anos depois também já se encontrava imprestável (COSTA, 1965, p. 224, p. 227-228). Antes disso, há inventário da própria ordem, datado de 1852, no qual se registrou o acervo das livrarias conventuais de Olinda, Recife, Igarassu e Paraíba, quando parte de suas obras seria incorporada à biblioteca da Faculdade de Direito do Recife. Por meio dele é possível perceber, mesmo que parcialmente, as preferências temáticas dos frades.

No que se refere à casa franciscana de Olinda, que abrigara os estudos teológicos superiores dos noviços seráficos, o dito inventário registra que sua livraria contava com 896 volumes, com alguns títulos apresentando diversos exemplares, praticamente todos já seriamente danificados, além de mais de 30 tomos de Teologia Dogmática que estariam, por empréstimo dos frades, na casa de um certo Dr. Farias (ALMEIDA, 2012, v. 2, p. 514). Em Igarassu, onde se ministravam as aulas dos estudos menores, se registrou a presença de 143 volumes na livraria (ALMEIDA, 2012, v. 2, p. 527-533), enquanto que, por sua vez, o mesmo inventário registrou 185 volumes no acervo da casa conventual da Paraíba (ALMEIDA, 2012, v. 2, p. 515-526). Os temas de maior recorrência na livraria paraibana resultam na Tabela 04 a seguir: 
Tabela 04 - Temas predominantes na livraria franciscana da Paraíba (Inventário de 1852 - 185 volumes) ${ }^{40}$

\begin{tabular}{l|l}
\hline \multicolumn{1}{c|}{ TEMAS PRINCIPAIS } & NÚMERO DE TíTULOS \\
\hline Estudos Bíblicos & 20 \\
\hline Teologia & 7 \\
\hline Moral Cristã & 5 \\
\hline Canto/ Coro & 5 \\
\hline Obras Marianas & 4 \\
\hline Doutrinas da Igreja/ Normas e Determinações Pontifícias & 4 \\
\hline Direito Canônico & 4 \\
\hline Ritualística & 3 \\
\hline Bíblias & 3 \\
\hline Outros & 3 \\
\hline Filosofia & 2 \\
\hline Obras Enciclopédicas & 1 \\
\hline Manuais Confessionais & 1 \\
\hline Dicionários & 1 \\
\hline História da Igreja & 1 \\
\hline Obras Franciscanas & 1 \\
\hline Fonte: dados da documentacão consulada, organizados & \\
\hline
\end{tabular}

Fonte: dados da documentação consultada, organizados pela autora.

Um detalhe do acervo paraibano se destaca de imediato: apesar de ser uma casa onde, ao longo de todo o Setecentos e esporadicamente no Oitocentos estava instalado um curso de gramática latina, não há o registro, ao menos no inventário de 1852, de obra alguma dedicada ao tema. $\mathrm{O}$ único dicionário inventariado é o Suplemento ao Vocabulário Portuguez e Latino, de Bluteau, que apresenta dois volumes na livraria. Daí se pode supor que as aulas de gramática utilizassem como base essencialmente as obras de temática religiosa, inclusos aí os volumes de estudos bíblicos e demais assuntos listados no inventário, e não obras clássicas de autores latinos, como se tornou comum nas aulas régias a partir de fins do Setecentos. Essa já se constituiria numa peculiaridade da instrução franciscana de gramática latina tanto nas aulas intra como nas extramuros.

O predomínio dos temas religiosos nas estantes da livraria paraibana, por outro lado, não surpreende. Era o usual no acervo das casas conventuais de praticamente todas as congregações religiosas no final do Setecentos em Portugal (CAMPOS, 2013), e não é de se esperar que algo diferisse muito nos cenóbios seráficos da Província de Santo Antônio do Brasil, portanto. É o que se pode constatar ao observar a listagem com as obras das livrarias conventuais de Salvador, Recife, Igarassu e Olinda, também registradas no

${ }^{40}$ APFR. Livro dos Inventários dos Conventos do Norte, em 5 de julho de 1852, feito por Fr. Antônio da Rainha dos Anjos Machado, 104 fólios. Alguns títulos aparecem com mais de um volume no acervo da livraria paraibana. 
mesmo inventário onde consta o acervo paraibano.

De resto, infelizmente, hoje não se tem qualquer ideia do que foi feito deste acervo e muito menos do cotidiano da livraria conventual, pois toda a documentação que lhe dizia respeito aparentemente se perdeu. É possível que alguns de seus volumes tenham ido parar no acervo da Biblioteca da Faculdade de Direito do Recife, já que o inventário de 1852 tinha por objetivo justamente levantar as obras que poderiam ser transferidas para lá. De fato, no caso da Província de Santo Antônio do Brasil há, certamente, uma extensa lacuna a preencher tendo os livros e as práticas de leitura e instrução no universo franciscano como mote principal de pesquisa, mas uma aproximação ao tema por intermédio da História da Educação vem abrindo novas possibilidades de investigação, ajudando a construir uma visão mais clara sobre a real importância da Ordem dos Frades Menores, no Brasil, para a estruturação da instrução dentro e fora dos conventos. Marcos Almeida destaca justamente este ponto em sua tese de doutorado:

Os franciscanos investiram em suas bibliotecas e na formação intelectual de seus membros. Ainda hoje, a riqueza dessas bibliotecas está longe de ser apreciada em seu verdadeiro valor, e acreditamos que é do interesse de todos para começar a identificar obras que podem estar ligadas a futuras pesquisas muito promissoras sobre o pensamento franciscano no Brasil. ${ }^{41}$ (ALMEIDA, 2012, v. 1, p. 11).

\section{Como que fazendo um arremate}

A atuação dos franciscanos na Instrução, ao menos no que se refere à Província de Santo Antônio do Brasil nos séculos XVIII e XIX e, de modo mais específico, à Paraíba, mostra-se como um campo muito promissor aos estudos da História da Educação, como se pretendeu demonstrar até aqui neste artigo. Certamente há muito ainda a se descobrir não apenas na própria documentação seráfica, mas também nos avulsos do Arquivo Histórico Ultramarino que, de certa forma, podem esclarecer detalhes dessa presença e, mais ainda, ampliar significativamente o escopo daquilo que se conhece atualmente sobre o tema.

O próprio Fr. Willeke, um dos historiadores mais diletantes da ordem de Assis no Brasil do século passado, destacava a presença dos franciscanos no ensino durante todo o período colonial já em 1961, diferenciando-o substancialmente daquele praticado pelos inacianos quanto ao público atingido:

[...] Enquanto as escolas dos Jesuítas de preferência visavam às cidades, as escolas dos franciscanos beneficiavam o interior, onde os padres seculares na qualidade de capelães dos engenhos de açúcar instruíam tão somente os filhos da chamada 'Casa Grande', ficando porém os povoados dependentes da caridade dos filhos de S. Francisco. (WILLEKE, 1961, apud MIRANDA, 1969, p. 199).

A relação entre instrução, livros e livrarias, por outro lado, mostra-se de fato como um tripé indissociável, sem o qual não é possível perceber, ao menos de modo aproximado, como se dava o ensino entre os frades menores, tanto no que se refere à formação de religiosos como também nas aulas extramuros.

\footnotetext{
$41 \mathrm{O}$ texto original: "Les franciscains investissent dans leurs bibliothèques et la formation intellectuelle de leurs membres. Aujourd'hui encore, la richesse de ces bibliothèques est loin d'être appréciée à sa juste valeur, et nous pensons qu'il est de l'intérêt de tous de commencer à répertorier des ouvrages qui peuvent donner lieux à de futures recherches très prometteuses sur la pensée franciscaine au Brésil".
} 
As ideias e visões de mundo dos irmãos seráficos por certo orbitavam os discursos impressos nas obras de suas livrarias conventuais, assim como provavelmente eram reproduzidos nas aulas de gramática latina, Filosofia e Teologia, ministradas na Província de Santo Antônio do Brasil entre o Setecentos e o Oitocentos. Aqui se pretendeu apenas construir uma primeira aproximação com o tema, que se mostra desde já tão rico e propício a outras e mais extensas pesquisas no campo da História da Educação.

\section{Referências}

ALMEIDA, Marcos Antonio de. L'Orbe Serafico, Novo Brasilico: Jaboatão et les franciscains à Pernambouc au XVIIle siécle. 2 vols. 2012. Tese (Doutorado em História Moderna) - Centre d'Études et de Recherches Sur les Mondes Américains, École des Hautes Études em Sciences Sociales/EHESS, Paris, 2012.

ANDRADE, António Alberto Banha de. A reforma pombalina dos estudos secundários (1759-1771): contribuição para a História da Pedagogia em Portugal. 2 vols. Coimbra: Universidade de Coimbra, 1981.

ATAS Capitulares da Província Franciscana de Santo Antônio do Brasil (1649-1893). Introdução e notas de Fr. Venâncio Willeke, OFM. Revista do Instituto Histórico e Geográfico Brasileiro, Rio de Janeiro, v. 286, p. 92-222, jan./mar. 1970.

BAZIN, Germain. A arquitetura religiosa barroca no Brasil. 2 vols. Tradução de Glória Lúcia Nunes. Rio de Janeiro: Record, 1983 [1956].

BLUTEAU, Raphael. Vocabulario portuguez \& latino: aulico, anatomico, architectonico \& etc... 8 vols. Coimbra: Collegio das Artes da Companhia de Jesu, p. 1712-1728.

Disponível em: <http://dicionarios.bbm.usp.br/>. Acesso em: 19 abr. 2015.

BRAGA, Isabel M. R. Mendes Drumond. Bibliotecas particulares em Portugal e no Brasil: o testemunho das fontes inquisitoriais (séculos XVII-XVIII). In: ALVIM, Márcia Helena (Org.). Conhecimento, cultura e circulação de ideias na América colonial Luso-Hispânica. Santo André: Universidade Federal do ABC, 2014, p. 99-118.

CAMPOS, Fernanda Maria Alves da Silva Guedes de. Bibliotecas de História: aspectos da posse e uso dos livros em instituições religiosas de Lisboa nos finais do século XVIII. 2 vols. 2013. Tese (Doutorado em História) - Faculdade de Ciências Sociais e Humanas, Universidade Nova de Lisboa/UNL, Lisboa, 2013.

CONDE, Antónia Fialho. O mosteiro de S. Bento de Cástris e a décima eclesiástica. Revista Portuguesa de História, Coimbra, Tomo XXXVI, v. 1, p. 161-172, 2002/2003.

COSTA, Francisco Augusto Pereira da. Anais Pernambucanos - Vol. IX: 1824-1833. 2. ed. Recife: Arquivo Público Estadual, 1965.

ESTATUTOS da Província de S. Antonio do Brasil. Lisboa: Na Officina de Manoel \& Joseph Lopes Ferreyra, MDCCIX [1709]. Disponível em: <http://purl.pt/>. Acesso em: 02 jan. 2012.

FERNANDES, Cybele Vidal Neto. Considerações sobre o espaço na obra franciscana no Brasil. In: FERREIRA-ALVES, Natália Marinho (Org.). Os franciscanos no mundo português III: o legado franciscano. Porto: CEPESE, 2013, p. 281-307.

GANHO, Maria de Lourdes Sirgado. Bibliotecas monásticas e cultura. Didaskalia, Lisboa, v. XXIV, p. 139-144, 1994.

IGLESIAS, Tania Conceição. A experiência educativa da Ordem Franciscana: aplicação na América e sua influência no Brasil colonial. 2010. Tese (Doutorado em Educação) - 
Universidade Estadual de Campinas, Campinas, 2010.

. Os franciscanos e a primeira experiência missionário-educativa no Brasil colonial (1538-1548). In: TOLEDO, Cézar de Alencar Arnaut; RIBAS, Maria Aparecida de Araújo Barreto; SKALINSKI JR., Oriomar (Orgs.). Origens da Educação escolar no Brasil colonial - v. I. Maringá: EDUEM, 2012, p. 115-147.

JABOATAM, Fr. Antonio de Santa Maria (OFM). Novo Orbe Serafico Brasilico ou Chronica dos Frades Menores da Província do Brasil. 2 vols. Rio de Janeiro: Typographia Brasiliense de Maximiano Gomes Ribeiro, 1858. Disponível em: <http://books.google.com.br/>. Acesso em: 02 jul. 2010.

LOIZAGA, Saturnino Ruiz de. La biblioteca de un convento franciscano: San Bartolomé de Santa Gadea del Cid (Burgos) (1710-1740). Scriptorium Victoriense, Vitoria-Gasteiz, v. 55, n. 1/2, p. 197-226, 2008.

MIRANDA, Maria do Carmo Tavares de. Os franciscanos e a formação do Brasil. Recife: Universidade Federal de Pernambuco, 1969.

MUELLER, Fr. Bonifácio (OFM). Convento de Santo Antônio do Recife (1606-1956): esbôço histórico. Recife: Imprensa Oficial, 1956.

SANTOS, Mônica Costa. Missionários de letras e virtudes: a Pedagogia Moral dos franciscanos em Alagoas nos séculos XVIII e XIX. 2007. Dissertação (Mestrado em Educação Brasileira) - Programa de Pós-Graduação em Educação, Universidade Federal de Alagoas/UFAL, Maceió, 2007.

SILVA, Luiz Antonio Gonçalves da. Bibliotecas brasileiras vistas pelos viajantes no século XIX. Ciência da Informação, Brasília, v. 39, n. 1, p. 67-87, jan./ abr. 2010.

VILLALTA, Luiz Carlos; MORAIS, Christianni Cardoso de; MARTINS, João Paulo. As reformas pombalinas e a instrução (1759-1777). In: FALCON, Francisco; RODRIGUES, Claudia (Orgs.). A "época pombalina" no mundo luso-brasileiro. Rio de Janeiro: Editora FGV, 2015, p. 453-498.

WILLEKE, Fr. Venâncio (OFM). Convento de Santo Antônio de Ipojuca. Revista do Patrimônio Histórico e Artístico Nacional, Rio de Janeiro, SPHAN, Ministério da Educação e Cultura, n. 13, p. 255-358, 1956.

XAVIER, Ângela Barreto. Les bibliothèques virtuelles et réelles des franciscains en Inde au XVIle siècle. In: CASTELNAU-L'ESTOILE, Charlotte de; COPETE, Marie-Lucie; MALDAVSKY, Aliocha; ZUPANOV, Ines G. (Orgs.). Missions d'évangélisation et circulation des savoirs: XVle-XVIIle siècle. Madri: Casa de Velázquez, 2011, p. 151-169.

CARLA MARY S. OLIVEIRA é historiadora e Doutora em Sociologia pela Universidade Federal da Paraíba. Realizou estágio pós-doutoral junto ao Programa de Pós-Graduação em História da Universidade Federal de Minas Gerais em 2009, com o financiamento de uma bolsa Capes/Procad-NF. Professora Associada do Departamento e do Programa de PósGraduação em História da Universidade Federal da Paraíba. Líder do Grupo de Pesquisa Arte, Cultura e Sociedade no Mundo Ibérico (séculos XVI a XIX) (Diretório CNPq/ PPGHUFPB). Membro do Grupo de Pesquisa História da Educação no Nordeste Oitocentista Gheno (Diretório CNPq/PPGH/PPGE-UFPB). Membro da Sociedade Brasileira de História da Educação.

Endereço: Departamento de História - Universidade Federal da Paraíba - Centro de Ciências Humanas, Letras e Artes; Cidade Universitária - Conjunto Humanístico - Bloco V - Castelo Branco - 58.051-970 - João Pessoa/PB - Brasil.

E-mail: cms-oliveira@uol.com.br 
Recebido em 02 de maio de 2016.

Aceito em 13 de outubro de 2016. 